\title{
Amalgamation and Small-Scale Gold Mining at Ancient Sardis, Turkey
}

\author{
William E. Brooks ${ }^{1}$, Hüseyin Öztürk², Zeynep Cansu ${ }^{2}$ \\ ${ }^{1}$ Geologist, Reston, VA, USA \\ ${ }^{2}$ Department of Geological Engineering, Istanbul University, Istanbul, Turkey \\ Email: webgeology@aim.com
}

How to cite this paper: Brooks, W. E., Öztürk, H., \& Cansu, Z. (2017). Amalgamation and Small-Scale Gold Mining at Ancient Sardis, Turkey. Archaeological Discovery, 5, 42-59.

http://dx.doi.org/10.4236/ad.2017.51003

Received: January 3, 2017

Accepted: January 22, 2017

Published: January 25, 2017

Copyright (@) 2017 by authors and Scientific Research Publishing Inc. This work is licensed under the Creative Commons Attribution International License (CC BY 4.0).

http://creativecommons.org/licenses/by/4.0/

Open Access

\begin{abstract}
In the ancient world gold was mined mainly from alluvial occurrences using gravity methods combined with the use of mercury (amalgamation), a method that is still used today in small-scale alluvial gold mines worldwide. Cyanide, which was first used in the 1880s, is used in large-scale hardrock mines to recover gold, silver, copper, and other metals from porphyry and disseminated ore deposits. Therefore, amalgamation must be considered, or specifically in the case of Sardis, reconsidered as the technology for ancient alluvial gold mining. Evidence that includes: the availability of cinnabar, the ore of mercury; an ancient mercury retort; ancient use of cinnabar as a pigment and mercury for gilding and amalgamation; the very fine-grained alluvial gold at Sardis; and the composition of the end-product gold, a Byzantine coin. These all indicate that amalgamation must be considered as the mining technology that supplied gold to Sardis' ancient refineries and craftsmen.
\end{abstract}

\section{Keywords}

Gold, Mercury, Amalgamation, Sardis, Turkey

\section{Introduction}

Amalgamation is widely used today in small-scale alluvial gold mines around the world and this method is key to understanding alluvial gold mining in the past that would have similarly utilized gravity separation of gold combined with mercury amalgamation. It is a rudimentary process that begins with washing the gold-bearing sediment to obtain a gold-bearing pan concentrate; then adding mercury to amalgamate the gold; then removing the gold-mercury amalgam; and finally, burning the amalgam to volatilize the mercury leaving the gold. As used herein, gold refers to the platinum-silvercopper bearing alluvial gold, or electrum found at, for example, the Pactolus River gold occurrence at Sardis (SartÇayi, Manisa), Turkey (Figure 1). 


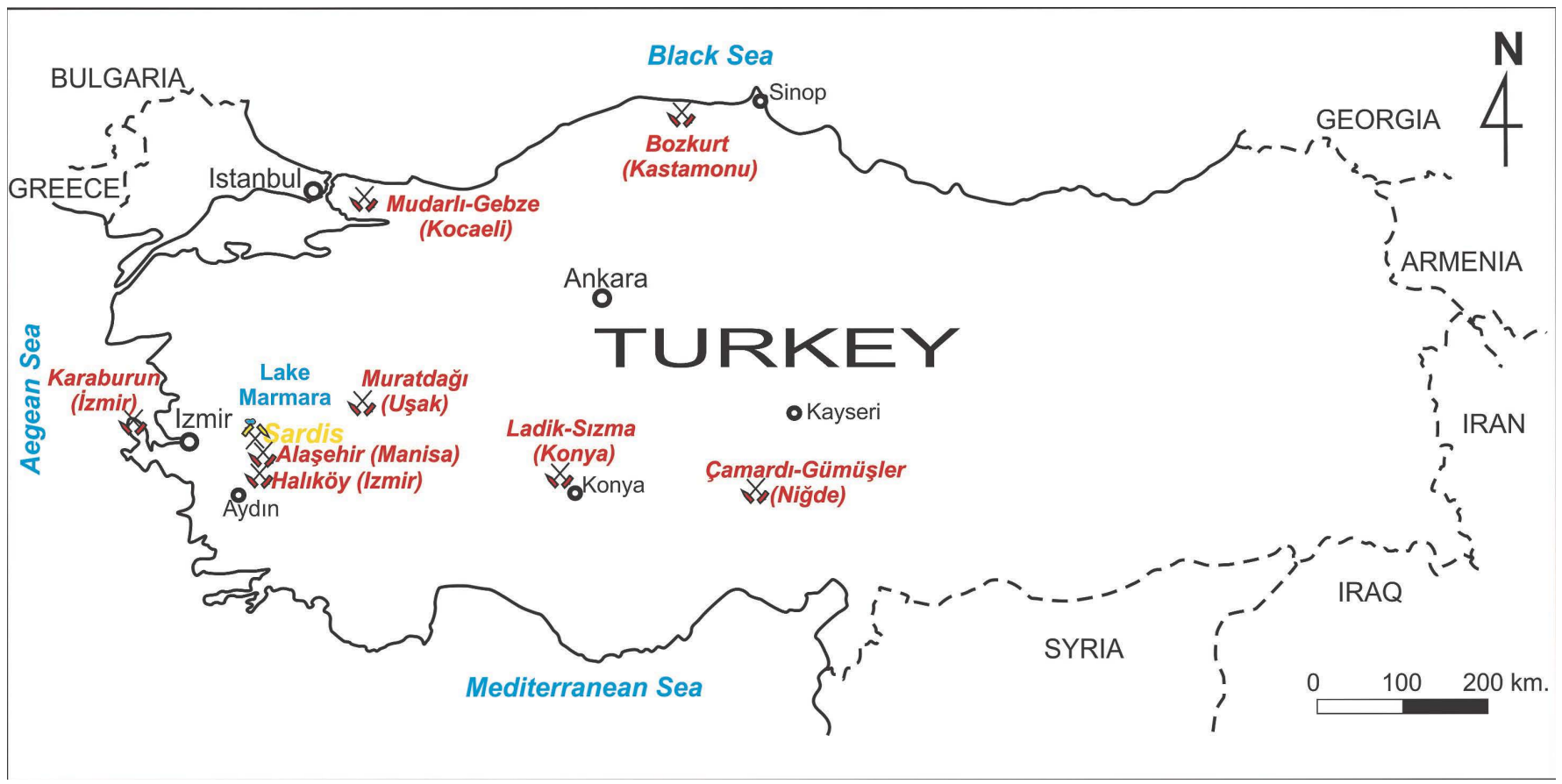

Figure 1. Approximate locations of mercury districts in Turkey (Bircan \& Aydoğanl1, 1969; Barnes \& Bailey, 1972).

Gold mining in western Turkey goes back to $\sim 3000 \mathrm{BC}$ and alluvial gold was mined from Astrya approximately $25 \mathrm{~km}$ from ancient Troy (Bayburtoğlu \& Yildirim, 2010). At Sardis, alluvial gold mining dates to $\sim 700 \mathrm{BC}$ and gold is still produced today. However, owing to the small size of the gold at Sardis, it was necessary to use mercury to amalgamate the gold-bearing sluice concentrates as part of a modern economic evaluation of this ancient gold occurrence (Topkaya, 1984).

Amalgamation, which dates at least to Roman times (Agricola, 1556/1912), was proposed as the mining technology used at ancient Sardis (Craddock, 2000a) -that is, if mercury had been used, then low levels of mercury would be detected in the chemical analyses of the end-product gold. Therefore, gold coins from the British Museum's Sardis collection were analyzed (SEM-EDX), and since no mercury was detected in the coins, Craddock (2000a) concluded that amalgamation had not been used.

However, there are basically only two methods to mine gold: 1) the centuries-old use of gravity combined with the addition of mercury (amalgamation); and 2) the comparatively recent use of cyanide. The cyanide method dates to the 1880s (Craig et al., 2011) and therefore, chronologically, amalgamation must be reevaluated as the technology for small-scale alluvial gold mining at ancient Sardis.

\section{Alluvial Gold Mining and Mercury}

Placer, or alluvial gold was ancient man's primary source of gold and provided twothirds of the gold that was ever produced (Boyle, 1979; Bayburtoğlu \& Yildirim, 2010). Nuggets and coarse gold would have been easily picked from the streams and gold pans; however, recovering the fine-grained gold would have required: 1) washing the gold-bearing sediment to eliminate light minerals thereby leaving a gold-bearing heavy mineral concentrate known as "black sand" which would have included zircon, cinna- 
bar, magnetite, platinum, and other heavy minerals, 2) selective removal of the gold from the black sand by the addition of mercury (amalgamation), 3) and then, as now in Colombia, Ecuador, Guyana, Perú, and Venezuela, burning the amalgam (Spanish, refogado) to volatilize the mercury and recover the gold (Brooks et al., 2007; Brooks et al., 2013; Brooks, 2014).

Sardis was the capital of the ancient kingdom of Lydia and was the western stronghold of the Persian Empire following its capture by Cyrus in 546 BC. A major trading route with ancient Persia, the Royal Road, terminated at Sardis (Akurgal, 1969) and the region has been called the cradle of metallurgy. Sardis' mineral wealth, especially gold, and the use of other mineral resources, is exquisitely demonstrated by a $5^{\text {th }}$ century BC gold earring, with platinum (iridium, osmium), that also incorporated cinnabar in the design (Young, 1972; Bayburtoğlu \& Yildirim, 2010). Gold from Sardis was used for jewelry, pendants, and chains (Curtis, 1925), or more importantly, was parted to recover silver and gold for coins as early as the $7^{\text {th }}$ century BC (Craddock, 1995; Ramage \& Craddock, 2000). Gold appliqués were associated with some ancient funeral rites and were also attached to clothing (Roosevelt, 2009; Ephesus Museum, 2016). In the Byzantine world that included parts of Spain, Italy, North Africa, and Asia Minor (Turkey), cinnabar, the ore of mercury, was used as a pigment (vermilion), as a funeral preservative, and retorted to produce mercury that was used for gilding or amalgamation.

The earliest written description of the use of mercury specifically for alluvial gold mining was given by al-Biruni, an $11^{\text {th }}$ century Persian scientist. Small pits in the Sind River bed were filled with mercury; the mercury amalgamated the alluvial gold and then the gold-mercury amalgam was recovered, squeezed in a cloth to remove some of the mercury, and then the gold was burned to volatilize the remaining mercury (al-Hassan \& Hill, 1986).

Any discussion of ancient gold mining in the region must reference the Golden Fleece, which is the legendary mining method used to recover alluvial gold at ancient Sardis (Healy, 1978; Higgins \& Higgins, 1996; Rapp, 2002). This method is analogous to the use of animal skins and carpets that are used in present-day small-scale gold mining in Perú and Venezuela in the initial stages of gold concentration; however, the final recovery of the fine-grained gold is done using mercury (Cánepa, 2005; Brooks et al., 2007). Several non-mercury methods for gold recovery are known in South America that include wind-winnowing in Perú (Spanish, aventadero) (Petersen, 1970/2010); the use of plant juices in Chocó, western Colombia (McDonald \& Hunt, 1982; Brooks et al., 2015); and a modern flotation system using biodegradable chemicals in Perú (Aquino, 2010). Several other ancient methods are discussed in Craddock (1995), however, none of these methods are as widely used or as productive as mercury amalgamation.

\section{Regional Setting}

Turkey is in the Tethyan Eurasian Metallogenic Belt that extends for roughly 10,000 km along the ancient Tethys seaway that separated the supercontinents of Gondwana and Laurasia during the Mesozoic Era. This ancient seaway tracked from Spain to northern India and was closed during the Miocene as a result of the collision of the African and Indian plate with the Eurasian plate. Therefore, Turkey's regional geologic setting is complex and includes colliding, sliding, and subducting tectonic plates that have pro- 
duced earthquakes, geothermal energy, and polymetallic ore deposits that contain gold, silver, mercury, lead, copper, and platinum. Most importantly, the cinnabar and gold occurrences of western and central Anatolia are Miocene and formed in a back-arc extensional regime similar to the Basin and Range province in the western US (Öztürk, 2015).

These metallic mineral deposits have been mined since ancient time and provided silver, copper, iron, lead, tin, and other metals used by the Romans and Greeks (Young, 1972; de Jesus, 1978, 1981; Yildiz \& Bailey, 1978; Yigit, 2006; Öztürk \& Hanilçi, 2009; Roosevelt, 2009; Hanilçi et al., 2010). Minerals such as sulfur were used to soften wool and pigments were obtained from limonite (yellow ochre), realgar (reddish-orange), and cinnabar (red) (Roosevelt, 2009). Coal is abundant in northern and western Turkey and is typically low-rank (lignite to subbituminous) (Palmer et al., 2004); however; thus far, there is only speculative evidence for the use of coal as a fuel in ancient time. Ancient Roman mining records have been found near Ovacik-Bergama, KucukdereHavran, and Sogut-Bilecik (Bayburtoğlu \& Yildirim, 2010).

Modern mercury mining in Turkey predates 1900 and the Turkish mining register for mercury began in 1923 (Murdock, 1958). Mercury production ended 1986 when the country produced 275 tons ( $\mathrm{t}$ ) ( $\sim 8000$ flasks) of mercury mainly from the mines at Karaburun and Konya (Roskill's, 1990). The mercury reserves of Turkey, mainly in the Aegean Region, are approximately 3820 metric tons (Turkish Ministry of Environment, 2010).

In 2011, Turkey produced $25 \mathrm{t}$ of gold from open-pit mines and, in 2016, Sardis was still operational and produced aggregate, quartz, perlite, and heavy minerals such as zircon and corundum for industrial use and gold only as a byproduct (Pomza Export, 2016; Turkish Gold Miners Association, 2016; Yigit, 2016). Other gold occurrences are known in western Turkey and there are numerous copper, tin, and lead occurrences throughout the country (de Jesus, 1978; 1981; Öztürk \& Hanilçi, 2009). Turkey has a gold endowment of approximately 31 million ounces; however, alluvial/placer deposits are limited and none are currently active with the exception of Sardis (Pomza Export, 2016; Yigit, 2016).

\section{Geologic Setting of Sardis}

Sardis is approximately $90 \mathrm{~km}$ east of Izmir (Figure 1) and, regionally, is underlain by metamorphic rocks (schist, phyllite, and marble) and younger sedimentary units composed of sandstone, conglomerate, and recent alluvium. Sardis' gold was initially deposited in veins in the metamorphic rocks and then, these rocks weathered and released the gold that was then transported and concentrated in a nearby basin (Higgins \& Higgins, 1996). These gold-bearing, poorly-sorted, basin-fill conglomerates (Figure 2(a)) were then cemented, uplifted (Figure 2(b)) and weathered again with the gold being reworked and redeposited in the alluvium of the Pactolus River. Therefore, gold at Sardis may be mined from: 1) uplifted, cemented quartz-pebble conglomerates, or 2) from the recent alluvium in the Pactolus River.

\section{Re-Consideration of Amalgamation at Sardis}

Amalgamation was considered as the mining technology used at Sardis and Craddock 


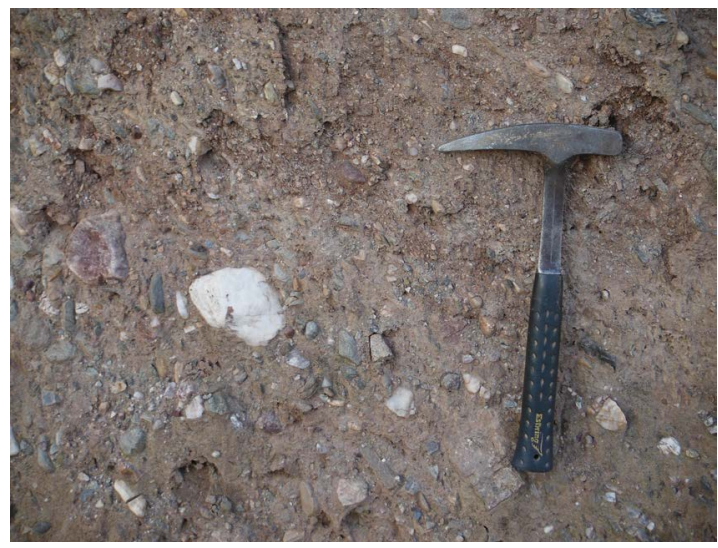

(a)

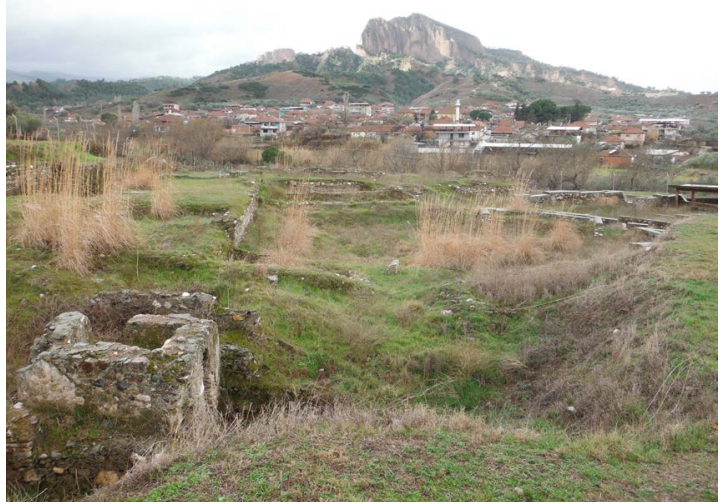

(b)

Figure 2. (a) Poorly sorted gold-bearing quartz pebble conglomerate at Sardis, Turkey; (b) faulted and uplifted basin-fill conglomerates at Sardis, Turkey. Sardis' ancient refinery is in the foreground.

(2000a) proposed that if mercury had been used to amalgamate the gold, then low levels of residual mercury would be detected in the analyses of the end-product gold. Therefore, coins from the British Museum's Sardis collection were analyzed (SEM-EDX), and since no mercury was detected, it was concluded that mercury had not been used.

Therefore, given Craddock's conclusion that amalgamation was not used at Sardis and to re-consider amalgamation as a mining technique at ancient Sardis, it is important to establish and integrate regional geoarchaeological evidence that includes: 1) geology and the availability of cinnabar and mercury, 2) archaeology and evidence for ancient mining and mercury processing such as an ancient mercury retort near Konya, 3) historical evidence such as regional Roman use of cinnabar as a pigment and as a source of mercury for gilding and amalgamation, 4) mining engineering implications for the recovery of the very fine-grained alluvial gold at Sardis from conglomerates and black sand, and 5) interpretation of the ICP analysis of end-product gold, a Byzantine coin (Table 1).

\subsection{Availability of Cinnabar and Mercury}

In Turkey, cinnabar ( $\mathrm{HgS})$, the most common ore of mercury is known in at least eight 
districts, all in western Turkey (Murdock, 1958; Ryan, 1960; Bircan \& Aydoğanl1, 1969; Barnes \& Bailey, 1972) (Figure 1). Archaeological evidence indicates that cinnabar was first mined in Turkey more than 8000 years ago-cinnabar was used as a pigment and was also retorted to obtain mercury as indicated by an ancient retort (Figure 3) found in the Sizma district, northwest of Konya. The Sizma mercury district is the most important mercury occurrence in Turkey and, based on gouges in the Büyük Maden mine

Table 1. ICP analyses from reconnaissance of mercury mines in Turkey.

\begin{tabular}{|c|c|c|c|c|c|c|c|c|c|}
\hline & TK161 & TK162 & TK163a & TK163b & TK164 & TK165 & TK166 & TK167 & TK168* \\
\hline $\mathrm{Au}(0.003)$ & 0.005 & 0.008 & $<0.003$ & 0.004 & $<0.003$ & 0.003 & 1.290 & 0.031 & $99.4 \%$ \\
\hline $\mathrm{Ag}(0.2)$ & $<0.2$ & 0.2 & $<0.2$ & $<0.2$ & $<0.2$ & $<0.2$ & 7.0 & $<0.2$ & \\
\hline As (2.0) & 11 & 2634 & 125 & 828 & 156 & 2149 & 599 & 592 & \\
\hline $\mathrm{Ca}(1.0)$ & 355162 & 42,603 & 2789 & 120,278 & 3258 & 1576 & 1244 & 3769 & \\
\hline $\mathrm{Cd}(0.1)$ & 0.3 & $<0.1$ & $<0.1$ & 0.3 & 0.3 & $<0.1$ & $<0.1$ & $<0.1$ & \\
\hline $\operatorname{Cr}(1.0)$ & 81 & 96 & 209 & 727 & 582 & 477 & 382 & 131 & \\
\hline $\mathrm{Cu}(1.0)$ & 9 & 1585 & 19 & 105 & 11 & 42 & 38 & 30 & \\
\hline $\mathrm{Fe}(10)$ & 7165 & 37,432 & 24,540 & 68,736 & 8398 & 101,353 & 14,695 & 36,497 & \\
\hline $\mathrm{Hg}(0.1)$ & 4.7 & 405.7 & 15.2 & 10.3 & 770.1 & 97.6 & 4.3 & 84 & $<1$ \\
\hline $\mathrm{La}(10)$ & 17 & 27 & 13 & 27 & $<10$ & $<10$ & 33 & $<10$ & \\
\hline $\operatorname{Mg}(1.0)$ & 4274 & 775 & 249 & 2027 & 293 & 400 & 452 & 5800 & \\
\hline $\operatorname{Mn}(1.0)$ & 346 & 152 & 46 & 310 & 64 & 182 & 58 & 418 & \\
\hline Mo (1.0) & 2 & 8 & 5 & 7 & 8 & 7 & 23 & 3 & \\
\hline $\mathrm{Ni}(1.0)$ & 2 & 13 & 74 & 775 & 76 & 679 & 51 & 52 & \\
\hline $\mathrm{P}(10)$ & 134 & 556 & 319 & 380 & 37 & 598 & 115 & 1510 & \\
\hline $\mathrm{Pb}(1.0)$ & 20 & 511 & 13 & 9 & 10 & 23 & 40 & 21 & \\
\hline $\mathrm{Pt}(0.1)$ & $\mathrm{Na}$ & na & na & na & na & na & $\mathrm{Na}$ & na & 1020 \\
\hline S (10) & 67 & 21,231 & 4686 & 6274 & 527 & 17,677 & 4728 & 1269 & \\
\hline $\mathrm{Sb}(0.3)$ & $<0.3$ & 181.1 & 19 & 132.8 & 12.4 & 141.7 & 1272.7 & 9.8 & \\
\hline $\mathrm{Se}(5.0)$ & 7 & $<5$ & $<5$ & $<5$ & $<5$ & $<5$ & $<5$ & $<5$ & \\
\hline Th $(0.1)$ & 1.7 & 11 & 9 & 8.5 & 3.0 & 7.8 & 9.2 & 8.9 & \\
\hline $\mathrm{Tl}(0.1)$ & 0.1 & 3.9 & 3.8 & 5.4 & 0.4 & 7.8 & 0.2 & 0.2 & \\
\hline $\mathrm{U}(0.1)$ & 0.1 & 0.3 & 1.6 & 3.0 & 0.6 & 1.1 & 1.1 & 0.6 & \\
\hline $\mathrm{V}(2.0)$ & 3 & 5 & $<2$ & 30 & $<2$ & 6 & 25 & 22 & \\
\hline W (1.0) & $<1$ & 2 & 1 & 7 & $<1$ & 1 & 3 & $<1$ & \\
\hline $\mathrm{Zn}(1.0)$ & 16 & 1011 & 14 & 292 & 16 & 78 & 201 & 101 & \\
\hline
\end{tabular}

Multi-element ICP analyses (parts per million; detection limit given to right of element, in parentheses; na-not analyzed; ${ }^{\star}$ fragment of ancient Byzantine gold coin, ore grade analysis for $\mathrm{Au}(\%), \mathrm{Hg}$ and $\mathrm{Pt}$ (ppm), with $\mathrm{Hg}$ detection limit of 1 ppm); American Assay, Sparks, NV, (SP0116032). Sample Descriptions: TK161 [0715294/4543335 UTM] near Koçaeli (Mudarli-Gebze); grab sample from calcite veins, reddish blebs, quartz, rusty pyrite along NS structure; several large meter-sized pits, not a major producing area; no hot springs evidence, no acid drainage; TK162 [454392/4275474] at Karaburun mine and plant, burned material from wall inside $\sim 4$ m well-constructed brick and basalt block chimney that served to vent gases from mercury plant that is downhill; TK163a [454392/4275474] at Karaburun; rock fragments from huge wastepile, some burned, reddened, scoriaceous fragments; TK163b [454392/4275474] at Karaburun; large [20 m $\times 100 \mathrm{~m} \times 100 \mathrm{~m}=\sim 200,000 \mathrm{~m}^{3}$ est.] wastepile, not as burned, not scoriaceous, but clearly crushed, perhaps volcanic material; TK164 [455395/4275406] at Karaburun; unaltered wastepile, gray silicified limestone, pyrite, rust stained; TK165 [455516/4274877] at Karaburun, area sample of hematite altered rock from mine area; TK166 [602834/4216521] at Haliköy Şubesi mine, sample of scoria on fire brick from chimney, all adits closed, cannot sample inside mine, no surface outcrops, mine now produces antimony; TK167 [602867/4216218] at Haliköy Şubesi, grab sample from dark, reddened, calcined tailings at ramp/loading area; TK168 gold coin ( 0.7 g sample). 

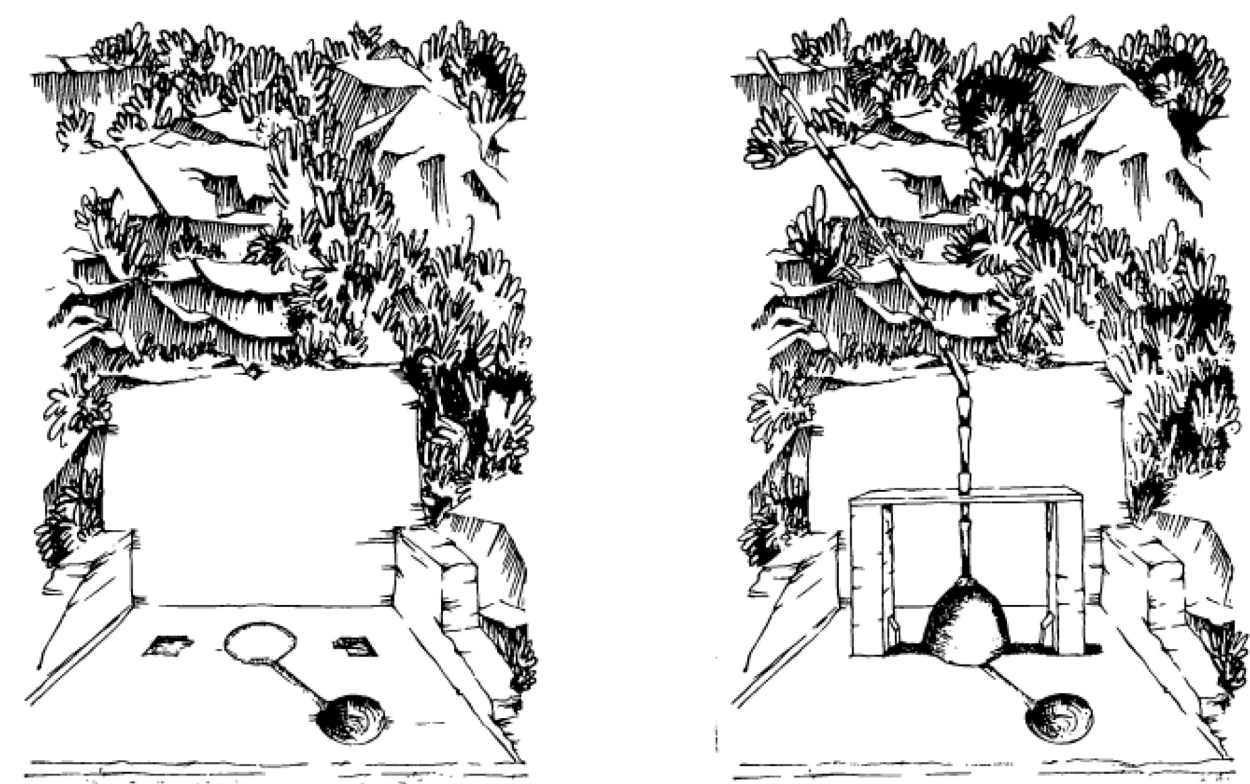

Figure 3. Sketch showing existing Konya retort site (left) and how it was probably used (right). Cinnabar was smelted, with charcoal, inside of an inverted ceramic bowl that served as a condenser. The ceramic flue eliminated sulfurous gases uphill and mercury collection trough is in lower right (Barnes \& Bailey, 1972).

where cinnabar veinlets had been worked, geologists indicate that Sizma was mined for its mercury by the Greeks and Romans as early as $6300 \mathrm{BC}$ and may be the world's oldest underground mine (Barnes \& Bailey, 1972; Yildiz \& Bailey, 1978).

Site visits-Aspart of this study, site visits were made to cinnabar/mercury occurrences at Mudarli-Gebze, Karaburun, and Haliköy (Figure 1) to determine mercury content of the ores, mine waste, and look for any evidence for ancient mining. Modern mining, however, has overprinted any archaeological evidence for ancient mining and the veins and interior of the mines are collapsed or are otherwise inaccessible. Therefore, geochemical sampling was limited to stockpiles, mine waste, and scoria from smelter stacks. At the Karaburun plant (Figure 4(a)) one sample from a stockpile contained $770 \mathrm{ppm}$ mercury (Figure 4(b)); a sample from a small, mined-out, hematite-altered open pit contained 97 ppm mercury; and samples from all locations contained 4.3 to $770 \mathrm{ppm} \mathrm{Hg}$ (Table 1). Burned material from inside the Karaburun chimney (Figure 4(c)) contained $405 \mathrm{ppm} \mathrm{Hg}$. Karaburun collectively refers to the Kalacik, Karareis, and Küçukbahçe mines that closed in the late 1980s; however, these mines have since contributed to mercury and heavy metal contamination in nearby marine sediments (Buyukisik et al., 2013).

Etibank, a Turkish company, was the largest producer of mercury in the 1970s and its Haliköy Şubesiplant produced mercury from the mines near Aydin (Figure 1) (Roskill's, 1990). Mine production has now shifted to antimony; however, calcined waste material from a loading area (Figure 5(a)) at Haliköy Şubesi contained $84 \mathrm{ppm}$ Hg (Figure 5(b)) (Table 1, TK167). A sample of scoria from inside the dismantled Haliköy Şubesi smelter stack contained 1.29 ppm Au, 7 ppm Ag, and 1272 ppm Sb (Figure 5(c); Table 1, TK166). 


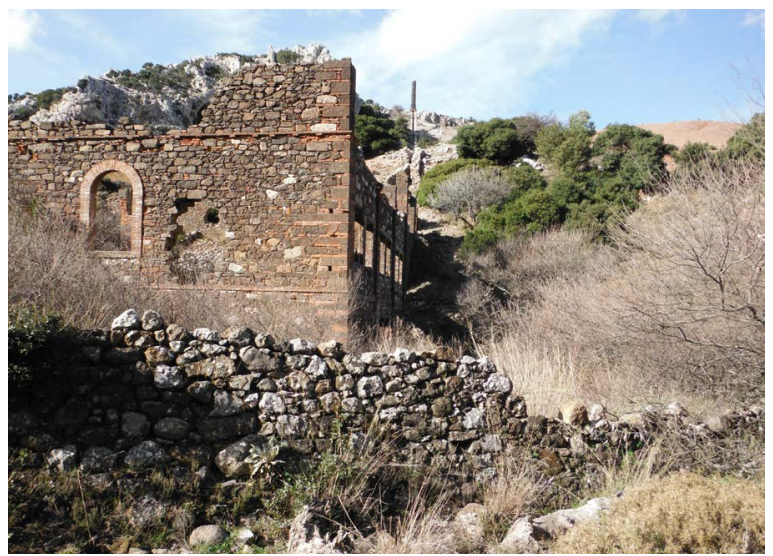

(a)

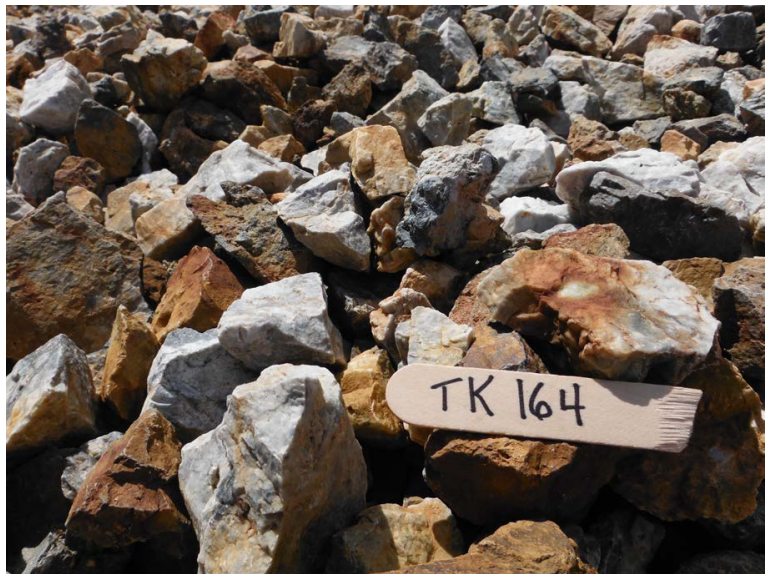

(b)

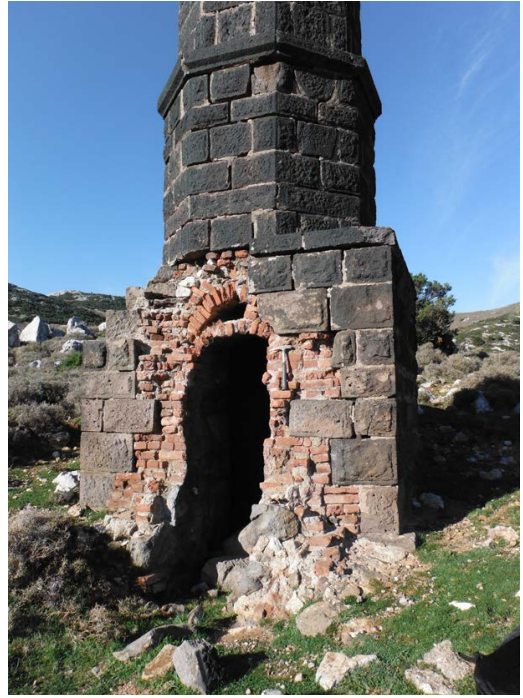

(c)

Figure 4. (a) Karaburun mercury plant in the foreground and the smelter chimney uphill in the distance. The rough rock wall in the foreground may indicate an older site; (b) Karaburun stockpile with a sample that contained 770 ppm Hg (Table 1; sample TK164); (c) Karaburun chimney from which an interior sample that contained 405 ppm Hg was taken (Table 1; sample TK162). 


\subsection{An Ancient Mercury Retort}

The Sizma mercury district, $\sim 6 \mathrm{~km}$ from Konya, has 15 mercury occurrences and is the most well-known mercury producing area in Turkey (Sharpless, 1908; Murdock, 1958). However, sometime around 1905, an English archaeologist discovered a tablet at an archaeological site near Konya (Figure 1) that was dedicated to Zizima, the ancient Phrygian goddess of mining, from which the name for the Sizma mercury district is derived (Barnes et al., 1969). Then, in 1905, an ancient cinnabar mine that had been used as a goat shelter was discovered in a cave near Konya. Deep grooves had been cut into the rock to follow the cinnabar veins and firesetting had been used to shatter the ore for removal. And, in 1969, $2 \mathrm{~km}$ south of Ladik, where most work had been at the Çirakmanand Muratdağ mines, also near Konya (Figure 1), a mercury retort (Figure 3) was found that demonstrates ancient cinnabar processing in the district. Greek and Latin inscriptions found on quarried marble blocks nearby document the age of the site (Murdock, 1958; Barnes \& Bailey, 1972). Even though the mines at Konya are now closed, mercury mining has contributed to heavy metal contamination in the region (Karahalil et al., 2012; Göktürk \& Özdemir, 2016).

The retort found near Ladik had been carved into marble, was $\sim 3 \mathrm{~m}$ on a side, and on the upper surface of the marble block was a $50 \mathrm{~cm}$ diameter circular depression with a $1 \mathrm{~cm}$ deep groove around the outside of the depression (Figure 3). The mercury ore, cinnabar, was mixed with fuel such as charcoal (coal?) in the depression, ignited, and then covered with an earthenware pot. The mercury would be collected as the volatilized mercury cooled and condensed on the walls of the pot and droplets of mercury would be recovered in the groove while sulfur would have been vented through a ceramic flue uphill and some distance away (Barnes et al., 1969; Barnes \& Bailey, 1972: p. 51). For comparison, the mercury plant at Karaburun has a similar geometric configuration; however, at a larger scale, to the ancient Konya site. The retorts were located downhill and a chimney to vent the sulfurous gases is uphill (Figure 4(a)). The composition of these volatilized retort gases is indicated by a scrape from the interior burned walls of the Karaburun chimney that contained 405 ppm mercury and 181 ppm antimony (Figure 4(c); Table 1, TK162).

In the region, ancient mercury processing, on a smaller scale, is also indicated by the Tepe Gawra pot (3500 BC) that has been interpreted as a Mesopotamian mercury retort (Levey, 1955).

Pigment-In the ancient world, cinnabar could be mined, ground, mixed with a binder, and used as a pigment (vermilion) without much additional processing (Lorenzi, 2004; Petersen, 1970/2010). Cinnabar was used as a funeral preservative in Spain 5000 years ago (Martín-Gil et al., 1995) and its use in ancient Turkey as part of an ancient funeral ritual is indicated by cinnabar-painted skulls found at an archaeological site $65 \mathrm{~km}$ southeast of Sizma that dates to 6280 BC (Barnes \& Bailey, 1972). And, as another example of cinnabar used as a pigment, a gold artifact from central Anatolia, The Seated Goddess with Child (Metropolitan Museum of Art, New York), shows that cinnabar was used for decoration on a gold figurine as early as the $13^{\text {th }}$ century BC. In Italy, the walls of ancient Pompeii were painted red with cinnabar more than 2000 years 


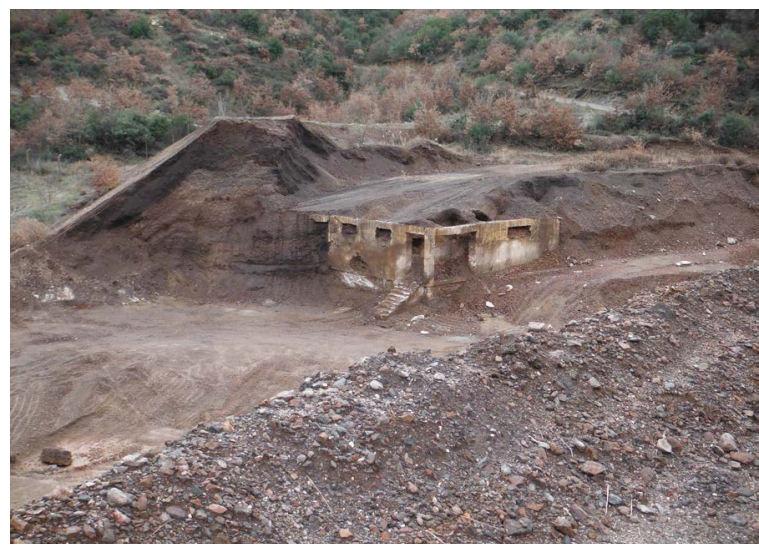

(a)

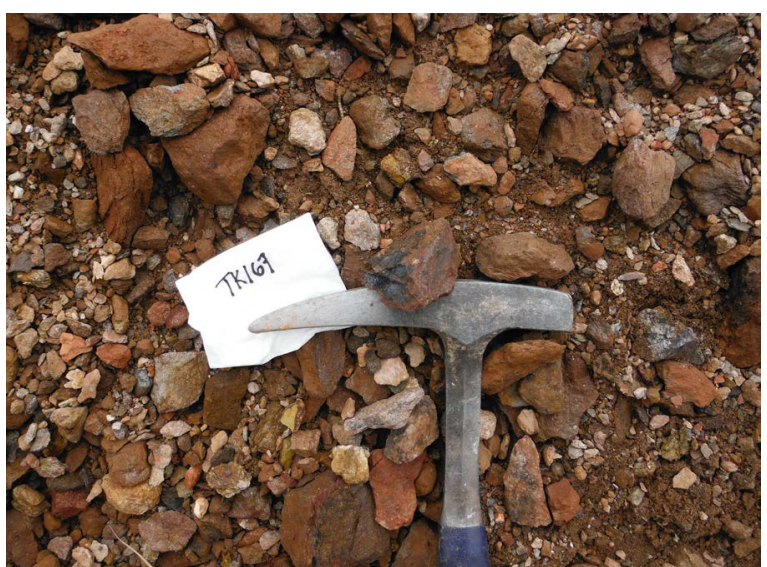

(b)

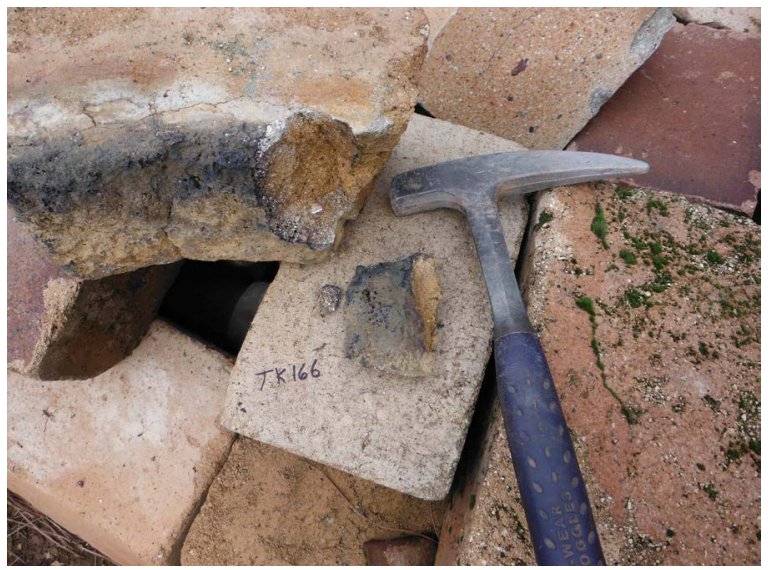

(c)

Figure 5. (a) Haliköy Şubesi mercury mine loading dock with calcined tailings; (b) Haliköy Şubesi loading dock tailings from which a sample with $84 \mathrm{ppm} \mathrm{Hg}$ was taken (Table 1, sample TK167); (c) Haliköy Şubesi smelter stack scoria with 1.29 ppm Au, 7 ppm Ag, 4 ppm Hg, and 1272 ppm Sb (Table 1; sample TK166).

ago (Lorenzi, 2004) and medieval stuccoes at the Alhambra, Spain were decorated with cinnabar (Burgio, 2005). And, even though cinnabar is toxic, it is still used for art applications today (Sax, 1984; Iconofile, 2010). 
Gilding and Amalgamation-Given, that cinnabar was the only mineral mined in the region, then it follows that the Konya retort (Figure 3) was used for processing cinnabar into mercury for ancient industrial uses such as gilding and gold amalgamation (Barnes \& Bailey, 1972).

Because of its malleability, gold may be hammered into a foil which can then be mechanically attached to paper, wood, stone, gypsum, or other metal surfaces. Fire-gilding implies mixture of gold flakes with mercury (Turkish, tombak, Archaeology Museum, Manisa) then application of the amalgam paste, followed by heating with a blowpipe to volatilize the mercury leaving a gilded surface.

Therefore, it is implicit to establish that the precursor to the gold foil must have been a gold "nugget" or ingot of some sort that could be hammered or otherwise crafted into a foil. Given the absence of gold nuggets at Sardis (Topkaya, 1984), then the source of this precursor "nugget" would have been an anthropogenic gold nugget (with some copper and silver) formed as the last stage of amalgamation when the mercury-gold amalgam is burned leaving a sponge-like texture in the button of gold (Spanish charpita, esponja, pepita, perla, piña) (Figure 6).

Examples of the use of gold foil can be found at the Archaeology Museum, Istanbul and also at the Hagia Sofia where the Byzantine Christ Pantocrator has a background formed from gold foil that was laminated between two sheets of glass which were broken and then used as the mosaic tesserae (written comm., Prof. L.E. Butler, Art History, George Mason University, 27 Sept. 2016).

\subsection{Regional Use}

In the Byzantine world, Almadén, Spain was described as a source of cinnabar and mercury as early as 332 BC (Bennett, 1948). Cinnabar was used to paint the walls of Roman villas at ancient Pompeii more than 2000 years ago (Lorenzi, 2004) and cinnabar was also used as makeup or as rouge. Sometimes referred to as "ruddle" in ancient literature, cinnabar was exported through the Black Sea port of Sinop (Figure 1) from

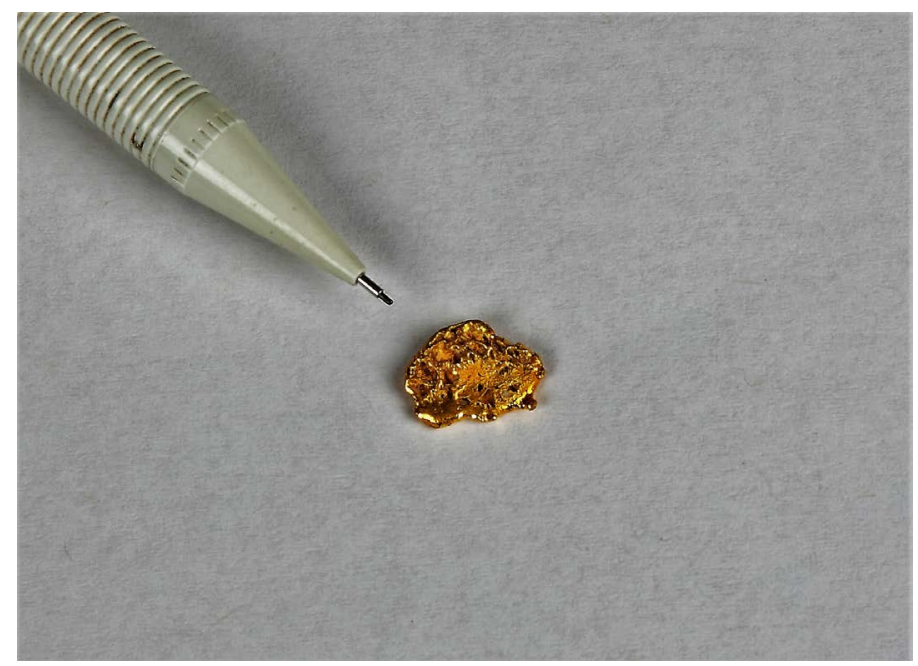

Figure 6. Anthropogenic gold nugget from Puerto Maldonado, Perú showing sponge-like texture resulting from burning (Spanish, refogado) the mercury-gold amalgam to volatilize the mercury. 
which the mineral name cinnabar may have been derived (Barnes \& Bailey, 1972). However, for this study it is important to acknowledge that by $77 \mathrm{AD}$, Rome imported $4-5 \mathrm{t}$ of mercury annually from the Spanish mines specifically for amalgamation (D'Itri \& D'Itri, 1977).

\subsection{Conglomerates, Black Sand, and Fine-Grained Gold at Sardis}

The sedimentary setting of the gold at Sardis has important regional implications that permit comparison with Byzantine gold mining at Las Médulas, Spain. Gold is a heavy mineral (specific gravity of $\sim 19$ ) and ubiquitous heavy minerals, such as magnetite and zircon contained in the black sand, must be removed. If available, nuggets can easily be recovered from an alluvial gold occurrence; however, recovering sufficient fine-grained gold such as at Sardis, for jewelry or coins would have been challenging.

Conglomerates-The gold at Sardis is hosted in reworked sedimentary rocks comprised of poorly sorted conglomerate and sandstone (Figure 2(a)). Additionally, the conglomerates have been faulted, uplifted, and are geomorphologically similar to the Las Médulas, Spain gold occurrence which was the most important gold occurrence mined by the Romans. At Las Médulas, the Romans developed and used hydraulic mining - this required a system of aqueducts that provided water under sufficient head to pressure-wash and degrade the outcrop which released the gold and then the muddy gold-bearing sediment was washed over riffles that trapped the gold particles (Domergue, 1990). The Roman miners, therefore, had experience with hydraulic mining which could have been used at Sardis.

However, is there any evidence for aqueducts or hydraulic mining at Sardis? There are at least $130 \mathrm{~m}$ of tunnels that were supposedly excavated to augment the water supply of ancient Sardis (Higgins \& Higgins, 1996); however, herein we offer an alternative interpretation that the tunnels were used to provide water to pressure-wash the gold-bearing Sardis conglomerates and are analogous to the aqueducts at Las Médulas.

Black Sand-Gold has a very high specific gravity ( 19) and when panned, minerals of high specific gravity (ex. rutile, 4.3; magnetite, $\sim$; zircon, $\sim 4.5$; cassiterite, 6.8 - 7.1; platinum, $\sim 14-19$;) may also be found in the gold pan concentrate. Therefore, a method that will selectively remove only the gold from the black sand, such as amalgamation, must be used. Even the Golden Fleece would not yield a pure gold concentrate and the persistent and abundant heavy minerals must be removed. At Sardis, the heavy mineral assemblage includes cassiterite, zircon, magnetite, garnet, rutile, ilmenite, chalcopyrite, pyrite, cinnabar, and hematite (Topkaya, 1984; Öztürk \& Hanilçi, 2009; Pomza Export, 2016). Gold separation is done today at the Pomza mine using several techniques, one of which is a sophisticated shaker, or Wilfley table, that uses a system of riffles and flowing water to sort the minerals according to specific gravity. Owing to the specific gravity and shape of the gold, the Wilfley provides a gold concentrate (Figure 7; Pomza Export; http://www.eilepomex.com). The heavy minerals are removed and sold as industrial minerals, and gold is recovered only as a byproduct.

Gold separation from alluvial material is difficult and, in another example, gold has also been recovered as a byproduct in California, western U.S., from black sand at sand and gravel operations by using: 1) magnetic, 2) high-tension, or 3) flotation methods. 
And, much like Sardis, the mineralogy of these California deposits includes black sand comprised of zircon, ilmenite, magnetite, and platinum-group metals (Gomes \& others, 1979). Therefore, at ancient Sardis, amalgamation would have been the only technology available to selectively remove the fine-grained alluvial gold.

Fine-Grained Gold-If available, nuggets would have been easily removed from the concentrates at ancient or modern Sardis mining operations. However, there are no museum samples, nor literature evidence to indicate that gold nuggets were ever found at Sardis (Topkaya, 1984), instead, the gold (Turkish, altin) is fine-grained and flattened (Figure 7). In a study of the economic potential of placer gold at Sardis, Topkaya (1984) described the gold flakes as very small with an average diameter of $\sim 30$ microns $(0.03 \mathrm{~mm})$ and the largest grain was $\sim 3 \mathrm{~mm}$. He concluded that, as a principal product, gold of this size would be difficult to recover, and therefore, not economic. His mining engineering evaluation of the Sardis deposit showed that free gold ranged from 9 - 130 $\mathrm{mg} / \mathrm{m}^{3}$ and, in order to make this determination, it was first necessary to recover the gold from sluice concentrates by amalgamation and then nitric acid was used to dissolve the mercury.

\subsection{Analysis of a Byzantine Gold Coin}

The final argument is geochemical, that is, determination of the amount of mercury, if any, contained in an end-product Byzantine gold coin (Figure 8). This follows Craddock's (2000a, p. 233) original proposal that if mercury had been used at Sardis, then low levels of mercury would be detected in the gold analyses. However, in those previous studies of gold from Sardis, mercury might not have been detected by non-destructive SEM-EDX because of: 1$)$ the potentially low levels of mercury $(<20$ ppm) as indicated by the South America gold studies (Brooks et al., 2013), and 2) the proximity of mercury and gold on the Periodic Chart and therefore, the lesser mercury peak, if present, would have been overshadowed by the stronger gold peak.

Turkish law will not allow catalogued artifacts such as gold coins or gold foils to leave

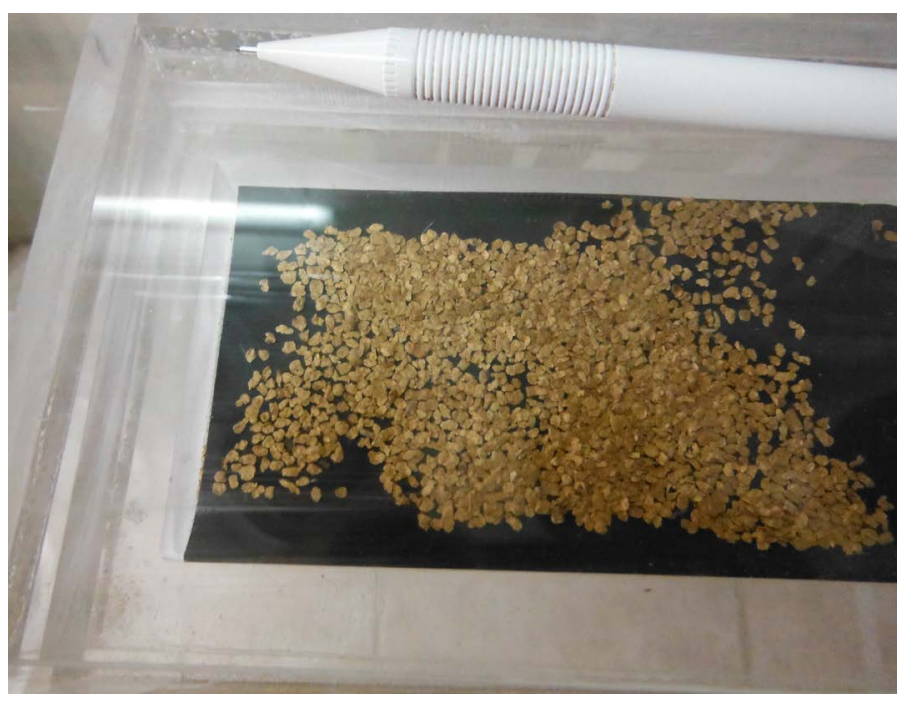

Figure 7. Byproduct gold concentrate at Pomza Export office showing flattened grains. 


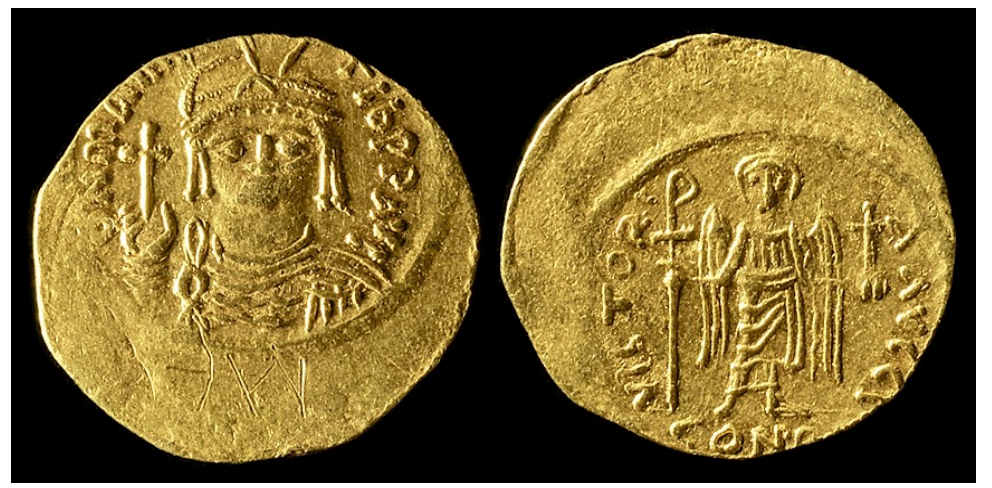

Figure 8. Gold coin (Table 1; sample TK168, with 99.4\% Au and 1020 ppm Pt); Byzantine Empire, Maurice Tiberius, struck 583 AD, Constantinople Mint. Helmeted and curassed facing bust holding globus cruciber, DM MAVRC TIB PP AVI/Angel standing facing holding long Chi-Rho-headed cross and globus cruciger, Victoria AVGGG officina letter I, CONOB below, ancient graffiti below bust, $22 \mathrm{~mm}, 4.37 \mathrm{~g}$. (Gabriel Vandevoort, URL http://www.ancientresources.com, accessed 1 March 2016).

the museums for analysis, much less be subjected to destructive analysis such as ICP. Therefore, an authenticated Byzantine gold coin was purchased in the U.S. and a $0.7 \mathrm{~g}$ portion was submitted for ICP analysis (Figure 8; Table 1, TK168). The data show that the coin is $>99.4 \%$ gold and $1020 \mathrm{ppm}$ platinum-gold is normally soft, malleable, and has a Moh's hardness of $\sim 2.5-3$, the naturally occurring platinum (iridium and osmium), with a Moh's hardness of $6-7$, would have given hardness and durability to Sardis' ancient coins. The gold content of this coin is comparable to the gold content (>99\%) of Sardis' coins analyzed by XRF (x-ray fluorescence) (Cowell \& Hyne, 2000). Most importantly, there is no mercury in the coin analyzed for this study, a fact that given the geologic and archaeologic evidence for amalgamation, must be discussed:

Mercury-Gold from alluvial sources in Colombia and Perú may contain 5000 ppm, or more, background mercury sourced from cinnabar/mercury outcrops, contamination from underground coal fires, alluvial gold mining in the region, or volcanic eruptions. Modern amalgam in the gold pan contains $>300,000 \mathrm{ppm} \mathrm{Hg}$-this amalgam must be burned, as would have been done in the past, to volatilize the mercury, leaving end-product gold with only trace amounts of mercury (Brooks et al., 2007). Pre-Columbian gold artifacts from museums in Bogotá and Lima typically contain $<20$ ppm mercury-consistent with a reduction of $>99 \%$ of the background $(\sim 5000 \mathrm{ppm})$ or amalgam ( 300,000 ppm) mercury content after two burns (Spanish, refogado) to volatilize the mercury (Brooks et al., 2013).

Microprobe analysis of Sardis alluvial gold indicates silver, copper, mercury, bismuth, lead, nickel, platinum (iridium, osmium), and several other elements in the gold; however, no ppm or percent was given (Topkaya, 1984). Therefore, we conclude that the mercury that was originally in the alluvial gold at Sardis, or mercury that was used for amalgamation, has been volatilized by at least three heating/burning episodes:

1) heat from a blowpipe (Spanish, refogado), as shown by (Craddock, 2000b; Roosevelt, 2009) that would have been analogous to the blowpipe (Spanish, soplete) used in pre-Columbian metallurgy or two burns using a gas torch used during modern amal- 
gam burning (Petersen, 1970/2010; Brooks et al., 2007; Brooks \& others, 2013) and subsequently, during the two-stage silver parting process at Sardis that included:

2) heating during salt cementation at temperatures of $\sim 650^{\circ} \mathrm{C}$ followed by

3) heating and parting of the silver at temperatures of $\sim 800^{\circ} \mathrm{C}$ (Craddock, 2000c), processes that ultimately provided pure gold and silver for coins (Meeks, 2000).

Gold foils with $4.7 \%$ - 17.3\% silver (Ramage \& Craddock, 2000) and gold-silvercopper foils (Spanish, tumbaga or Turkish, tombak) in the collection at the Archaeological Museum, Manisa (Ramage \& Craddock, 2000) would more closely represent the pre-parting composition of Sardis alluvial gold (Topkaya, 1984); however, neither mercury nor platinum content was reported for these samples. We interpret these gold-silver-copper foils as having been crafted from an anthropogenic gold-silver-copper bearing nugget resulting from amalgamation (Figure 6).

Platinum-Until $\sim 1900$, platinum was only known from gold-bearing alluvial sources (McDonald \& Hunt, 1982) and since platinum melts at $>1700^{\circ} \mathrm{C}$, it would have been little affected by amalgam burning and silver parting temperatures. Alluvial platinum is known at Sardis and microprobe analyses of a $5^{\text {th }}$ century $B C$ gold earring from the region indicated platinum (Young, 1972; Topkaya, 1984; Cowell \& Hyne, 2000). We interpret the platinum in the earring and gold coin $(1020 \mathrm{ppm})$ to indicate an alluvial source for the metals and not intentional alloying of the metals.

The amount of gold in the Byzantine coin, $>99 \%$, approaches the amount of gold in modern, very pure, highly refined mint or bullion gold expressed as 4 9s (9999) and demonstrates the efficiency of ancient Sardis' metallurgy. The platinum would have added hardness and durability to the malleable gold.

\section{Conclusion}

The geoarchaeological evidence presented herein such as availability of mercury, ancient retorts, and size of the alluvial gold grains is consistent with amalgamation as the mining technology used to recover the fine-grained alluvial gold at ancient Sardis. Amalgamation is a rudimentary process that requires mercury, which was retorted from cinnabar occurrences in the region, and recovering the gold from the amalgam requires heat to volatilize the mercury leaving the gold for continued processing into jewelry and coins. This process is widely used today in many small-scale alluvial gold mines around the world and provides a sound replication model for understanding alluvial gold mining in the ancient world.

\section{Acknowledgements}

I would like to express my respect and posthumous gratitude to Prof. Georg Petersen, Lima, Perú for introducing me to the application of geology and geochemistry to mining and metallurgical studies of archaeological materials in South America and simultaneously for his introduction to the Old World through his discussion of the alluvial gold occurrences at the Pactolus River. Sincere appreciation is expressed to my co-authors for collaboration in the field, providing access to maps and publications, introductions at mines and museums during our site visits, and confidence in this project. 


\section{References}

Agricola (1556/1912). De Re Metallica (638 p). Trans. by H. Hoover. NY: Kessinger Publishing. Akurgal, E. (1969). Ancient Civilizations and Ruins of Turkey(312 p). İstanbul: Mobil Oil Türk.

al-Hassan, A. Y., \& Hill, D. R. (1986). Islamic Technology: An Illustrated History (304 p). Cambridge: Cambridge University Press.

Aquino, M. (2010). Peruvian Eyes Green Gold to End Mercury Dumping. Reuters Business and Financial News.

https://business-humanrights.org/en/peruvian-eyes-green-gold-to-end-mercury-dumping

Barnes, J. W., \& Bailey, E. H. (1972). Turkey's Major Mercury Mine Today and How It Was Mined 8000 Years Ago. World Mining, 25, 49-55.

Barnes, J. W., Nackowski, M. P., \& Bailey, E. H. (1969). Geology and Ore Deposits of the Sizma-Ladik Mercury District, Turkey. Central Treaty Organization, 4th CENTO Training Program in Geological Mapping, July-September 1969, Istanbul, 225 p.

Bayburtoğlu, B., \& Yildirim, S. (2010). Gold and Silver in Anatolia. Bulletin of the Mineral Research and Exploration Institute of Turkey, 100, 1-25.

http://www.doganaydal.com/nesneler/kutuphanekitaplar/GOLD_AND_SILVER_IN_ANATO LIA_SON.PDF

Bennett, E. (1948). Almadén, World's Greatest Mercury Mine. Mining and Metallurgy, American Institute of Mining and Metallurgical Engineers, 29, 6-9.

Bircan, A., \& Aydoğanl, E. (1969). Inventory of Mercury in Turkey (52 p) [in Turkish]. Ankara: Mineral Research and Exploration Institute, Publication 143.

Boyle, R. W. (1979). The Geochemistry of Gold and Its Deposits. Canadian Geological Survey Bulletin, 280, $584 \mathrm{p}$.

Brooks, W. E. (2014). Colombia Mercury Inventory. Geología Colombiana, 37, 15-50.

Brooks, W. E., Sandoval, E., Yepez, M., \& Howard, H. (2007). Peru Mercury Inventory 2006. Open-File Report 2007-1252, U.S. Geological Survey.

http://pubs.usgs.gov/of/2007/1252/

Brooks, W. E., Schwörbel, G., \& Castillo, L. E. (2013). Amalgamation and Small-Scale Gold Mining in the Ancient Andes, Ch. 10. In N. Tripcevich, \& K. J. Vaughan (Eds.), Mining and Quarrying in the Ancient Andes, Interdisciplinary Contributions to Archaeology (pp. 213-229). New York, NY: Springer Publishing.

Brooks, W. E., Sierra-Giraldo, J. A., \& Mena, F. (2015). Green Gold-Dirty Gold, Tadó, Dept. Chocó, Colombia. Natural Resources, 6, 534-542.

https://doi.org/10.4236/nr.2015.611051

Burgio, L. (2005). Dating Alhambra Stuccoes. Conservation Journal, No. 49. http://www.vam.ac.uk/content/journals/conservation-journal/issue-49/dating-alhambra-stucc oes/

Buyukisik, H. B., Okan, Y. E., Sunlu, U., \& Turkdogan, M. (2013). Effects of Abandoned Kalecik Mercury Mine on the Marine Sediment, Karaburun, Izmir, Turkey. Rapp. Comm. Int. MerMédit. (Mediterranean Science Commission) 40. https://www.researchgate.net/publication275647149

Cánepa, C. (2005). Minería a Pequeña Escalaen La Costa Sur Media del Perú [Small Scale Mining in Southern Coastal Perú] (79 p.). Instituto Geológico Minero y Metalúrgico, Boletín 3, Lima.

Cowell, M. R., \& Hyne, K. (2000). Scientific Examination of the Lydian Precious Metal Coinages. In A. Ramage, \& P. T. Craddock (Eds.), King Croesus' Gold (pp. 169-174). London: British Museum Press.

Craddock, P. T. (1995). Early Metal Mining and Production (363 p.). Washington DC: Smithsonian Institution Press. 
Craddock, P. T. (2000a). Early History of the Amalgamation Process, App. 3. In A. Ramage, \& P. T. Craddock (Eds.), King Croesus' Gold (pp. 233-237). London: British Museum Press.

Craddock, P. T. (2000b). Reconstruction of the Salt Cementation Process at the Sardis Refinery, Ch. 10. In A. Ramage, \& P. T. Craddock (Eds.), King Croesus' Gold (pp. 200-211). London: British Museum Press.

Craddock, P. T. (2000c). Replication Experiments and the Chemistry of Gold Refining, Ch. 8. In A. Ramage, \& P. T. Craddock (Eds.), King Croesus' Gold (pp. 175-183). London: British Museum Press.

Craig, J. R., Vaughan, D. J., \& Skinner, B. J. (2011). Earth Resources and the Environment (508 p.). New York, NY: Prentice Hall.

Curtis, C. D. (1925). Jewelry and Goldwork, Part 1, 1910-1914, v. XII. Publications of the American Society for the Excavation of Sardis, Rome: Sindicato Italiano Arti Grafiche. http://www.fds.lib.harvard.edu/fds/deliver/400950965/CurtisSardisXII_IPDFA.pdf

D'Itri, P. A., \& D'Itri, F. M. (1977). Mercury Contamination, a Human Tragedy (311 p.). New York, NY: Wiley Interscience, John Wiley and Sons.

De Jesus, P. (1978). Metal Resources in Ancient Anatolia. Anatolian Studies, 28, 97-102. https://doi.org/10.2307/3642745

De Jesus, P. (1981). A Survey of Some Ancient Mines and Smelting Sites in Turkey (pp. 95-105). Mainz: Romisch-Germanisches Zentralmuseum.

Domergue, C. (1990). Les Mines de la Penínsule Ibérique Dansl' Antiquité Romaine [Mines of the Iberian Peninsula during Ancient Roman Time] (325 p.). Rome: École Française de Rome.

Ephesus Museum (2016). Sardis Beta Appliqué 120/61/87. http://www.sardisexpedition.org/en/artifacts/latw-142

Göktürk, F. A., \& Özdemir, C. (2016). Heavy Metal Accumulation in the Blood of Sheep Growing around the Sizma Region, Turkey. International Journal of Ecosystems and Ecology Science, 6. 625-630. http://www.paper.researchbib.com/view/paper/86447

Gomes, J. M., Martinez, G. M., \& Wong, M. M. (1979). Recovering Byproduct Heavy Minerals from Sand and Gravel, Placer Gold, and Industrial Mineral Operations (15 p.). U.S. Bureau of Mines Report of Investigations 8366.

Hanilçi, N., Altayli, C., Altuncu, S., \& Öztürk, H. (2010). Was the GolTepe a Tin Processing Site during the Early Bronze Age? In Preliminary Findings from Soil Geochemistry [abs.]: Analele Ştiințifice ale Universitații Al. I. Cuza, Proceedings of the Symposium Geology of Natural Systems (pp. 45-47). Ankara: Pucara.

Healy, J. F. (1978). Mining and Metallurgy in the Greek and Roman World (316 p.). London: Thames and Hudson.

Higgins, M. D., \& Higgins, R. (1996). A Geological Companion to Greece and the Aegean (240 p.). New York, NY: Cornell University Press.

Iconofile (2010). Natural Mineral Pigments, Cinnabar. http://www.iconofile.com

Karahalil, B., Ulukaya, M., \& Alp, O. (2012). Pilot Study of Environmental Monitoring of Konya Region near an Abandoned Mercury Mine in Turkey. Bulletin of Environmental Contamination and Toxicology, 88, 150-153. https://doi.org/10.1007/s00128-011-0435-4

Levey, M. (1955). Evidence of Ancient Distillation, Sublimation and Extraction in Mesopotamia. Centaurus, 4, 23-33. https://doi.org/10.1111/j.1600-0498.1955.tb00466.x

Lorenzi, R. (2004). Pompeii Artists Painted the Town Red. News in Science/Discovery News, Ultimo: Australian Broadcasting Corporation.

http://www.abc.net.au/science/news/stories/s1232875.html

Martín-Gil, J., Martín-Gil, F. J., Delibes-de-Castro, G., Zapatero-Magdaleno, P., \& Sarabia-Herrero, F. (1995). The First Known Use of Vermilion. Experentia, 51, 759-761. 
McDonald, D., \& Hunt, L. B. (1982). A History of Platinum and Its Allied Metals (450 p.). London: Johnson Matthey.

Meeks, N. D. (2000). Scanning Electron Microscopy of the Refractory Remains and the Gold, Ch. 5. In A. Ramage, \& P. T. Craddock (Eds.), King Croesus' Gold (pp. 99-156). London: British Museum Press.

Murdock, T. G. (1958). Mercury Deposits of the Konya Region, Turkey. U.S. Bureau of Mines Mineral Trade Notes, 47, 42-57.

Öztürk, H. (2015). Magmatism and Metallogeny of Western Anatolia, Turkey Associated with Subduction, Rollback, and Trench Retreat; A Comparison with the Basin and Range Province, USA-Mexico. In L. N. Kogarko (Ed.), Alkaline Magmatism of the Earth and Related Strategic Metal Deposits (158 p.). Boulder, Co Geological Soc. America.

Öztürk, H., \& Hanilçi, N. (2009). Metallogenic Evaluation of Turkey, Implications for Tin Sources of Bronze Age in Anatolia. Turkish Academy of Science Journal of Archaeology, 12, 105-116.

Palmer, C. A., Tuncali, E., Dennen, K. O., \& Finkelman, R. B. (2004). Characterization of Turkish Coals, a Nationwide Perspective. International Journal of Coal Geology, 60, 85-115.

Petersen, G. (1970/2010). Mining and Metallurgy in Ancient Perú (90 p.). Translation by Brooks, W. E., 2010, of Minería y Metalurgia en el Antiguo Perú, Arqueologicas 12, Museo Nacional de Antropología y Arqueología, Pueblo Libre, Lima, Perú. Geological Society of America Special Paper 467.

Pomza Export (2016). Pomza Export Mining Inc. Izmir. http://www.pomzaexport.com

Ramage, A., \& Craddock, P. (2000). King Croesus' Gold(272 p.). London: British Museum Press.

Rapp, G. R. (2002). Archaeomineralogy (326 p.). Berlin: Springer-Verlag. https://doi.org/10.1007/978-3-662-05005-7

Roosevelt, C. H. (2009). The Archaeology of Lydia, from Gyges to Alexander (314p.). New York: Cambridge University Press.

Roskill's (1990). The Economics of Mercury(140 p.). London: Roskill's Information Services Ltd.

Ryan, C. W. (1960). A Guide to the Minerals of Turkey (45 p.). Ankara: Mineral Research and Exploration Institute of Turkey.

Sax, N. I. (1984). Dangerous Properties of Industrial Minerals (124 p.). New York, NY: Van Nostrand Co.

Sharpless, F. F. (1908). Mercury Mines at Koniah, Asia Minor. The Engineering and Mining Journal, 87, 601-603.

Topkaya, Y. A. (1984). Recent Evaluation of the Sart Gold Deposit. In V. Kudryk, D. A. Corrigan, \& W. W. Liang (Eds.), Precious Metals, Mining, Extraction and Processing (pp. 85-101). Los Angeles: AIME.

Turkish Gold Miners Association (2016). History of Turkish Gold. http://turkishgoldminersassociation.org/turkish-gold/turkish-gold-history

Turkish Ministry of Environment (2010). Turkey's Position on Mercury. The Turkish Republic, Ministry of Environment and Forestry, Environmental Management Directorate. http://www.unep.org/chemicalsandwaste/Portals/9/Mercury/INC1/Turkey\%20submission.pdf

Yigit, O. (2006). Gold in Turkey, a Missing Link in Tethyan Metallogeny. Ore Geology Reviews, 28, 147-179. https://doi.org/10.1016/j.oregeorev.2005.04.003

Yildiz, M., \& Bailey, E. H. (1978). Mercury Deposits in Turkey (80 p.). U.S. Geological Survey Bulletin1456.

Young, W. J. (1972). The Fabulous Gold of the Pactolus Valley. Boston Museum Bulletin, 70, 4-13. 
Submit or recommend next manuscript to SCIRP and we will provide best service for you:

Accepting pre-submission inquiries through Email, Facebook, LinkedIn, Twitter, etc. A wide selection of journals (inclusive of 9 subjects, more than 200 journals) Providing 24-hour high-quality service

User-friendly online submission system

Fair and swift peer-review system

Efficient typesetting and proofreading procedure

Display of the result of downloads and visits, as well as the number of cited articles Maximum dissemination of your research work

Submit your manuscript at: http://papersubmission.scirp.org/

Or contact ad@scirp.org 